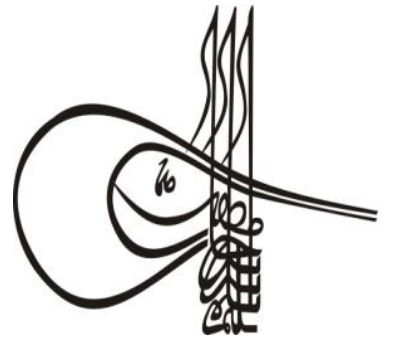

\section{Economics, Finance, Politics}

Volume 14 Issue 3, 2019, p. 761-780

DOI: 10.29228/TurkishStudies.23303

ISSN: 2667-5625

Skopje/MACEDONIA-Ankara/TURKEY

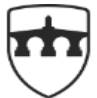

INTERNATIONAL BALKAN UNIVERSITY

EXCELLENCE FOR THE FUTURE IBU.EDU.MK

Research Article / Araştırma Makalesi

Article Info/Makale Bilgisi

Received/Geliș: 01.06.2019

$\checkmark$ Accepted/Kabul: 10.09.2019

This article was checked by iThenticate.

\title{
TÜRKİYE'DE GELİR DAĞILIMINDA ADALET VE YOKSULLAŞMA SORUNU: 2000 SONRASI DÖNEM ÜZERINE BİR ANALİZ
}

\author{
Süleyman ÇELIKK $K^{*}$ Soner KÜNÇ** - Safa ACAR ${ }^{* * *}$
}

\begin{abstract}
öz
Ekonomik büyüme, tüm dünya ülkeleri için temel iktisadi hedeflerden biridir. İktisadi büyüme ile elde edilen gelirin toplumsal sınıfların tümüne adil dağılımı ise kalkınmanın henüz tam olarak çözüm geliştirilememiş en önemli sorunlarından birisidir. Gelirin adil bir şekilde dağılımının gerçekleştirilememesi problemi genel olarak bütün ülkelerin karşlaştığ bir problem olup gelişmiş ve gelişmemiş ülkelerde benzer sorunlara yol açmaktadır. Elde edilen gelirin adil bir yapıda dağılımının sağlanamaması sonucu ortaya çıkan sorunlar daha büyük problemlere de yol açmaktadır. Bunun sonucunda karşılaşılan yoksulluk, önemli bir sosyo-ekonomik problem olarak ortaya çıkmaktadır. Ekonomiler genel olarak incelendiinde gelir dağılımı adalatsizliği ile yoksulluk düzeylerinin birbirleri ile yoğun bir şekilde ilişkili olduğu görülmektedir. Bu sebeple ekonomik kalkınma amacıyla yürütülen politikalar yoksulluk ile mücadele ve gelir dağılımının adil bir yapıya kavuşturulabilmesi konularını birlikte ele alarak stratejik birer hedef olarak belirlemektedir.
\end{abstract}

$\mathrm{Bu}$ çalışma, Türkiye'de 2000 yılı sonrasındaki dönemde, yoksulluk ve gelir eşitsizliği göstergelerinin ortaya koyduğu istatistik verilerinin kullanılarak Türkiye'nin aynı dönemde uyguladığı sosyal politikaların başarısını analiz etmeyi amaçlamaktadır. Yapılan analizde, özellikle 80 sonrasında ortaya çıkan gelir dağılımındaki uçurumun kapatılmasına yönelik çalışmaların başarılı sonuçlar verdiği, ancak yoksullukla mücadele kapsaminda uygulanan sosyo-ekonomik

Öğr. Gör., Siirt Üniversitesi Kurtalan MYO, E-posta: celik.slymn@ gmail.com

Öğr. Gör., Gaziantep Üniversitesi, Sosyal Bilimler MYO, E-posta: snr.knc@ hotmail.com

Öğr. Gör., Siirt Üniversitesi Kurtalan MYO, E-posta: safaacar@ siirt.edu.tr 
politikaların, nispi düzeylerde sonuçlar verdiği görülmüştür. Genel olarak elde edilen bulgular çerçevesinde bir değerlendirme yapıldığında, yoksulluk ve gelir dağılımı alanlarında nispi bir başarının sağlandığı görülmüş ancak yaşanan iyileşme düzeyinin uluslararası boyutlarda değerlendirildiğinde, elde edilen başarının yeterli olmadığ sonucuna ulaşılmıştır.

Anahtar Kelimeler: Gelir Dağılımı, Gelir Eşitsizliği, Yoksulluk, Türkiye.

\title{
THE PROBLEM OF JUSTICE AND IMPOVERISHMENT INCOME DISTRIBUTION IN TURKEY: AN ANALYSIS ON THE PERIOD AFTER 2000
}

\begin{abstract}
Economic growth is one of the main economic goals for all countries in the world. The fair distribution of income generated by economic growth among all social classes is one of the most important problems of development that has not yet been fully solved. The problem of inequitable distribution of income is a problem faced by all countries in general and leads to similar problems in developed and underdeveloped countries. The problems arisen as a result of not achieving a fair distribution of the income obtained also lead to bigger problems. As a result, poverty is an important socio-economic problem. When the economies are analyzed in general, it is seen that income distribution injustice and poverty levels are intensely related to each other. For this reason, the policies carried out for the purpose of economic development are considered as strategic targets by combating poverty and achieving a fair structure of income distribution.

This study, in the period after 2000 in Turkey, Turkey's poverty and income inequality using data statistics revealed by the indicators applied in the same period aims to analyze the success of social policy. In the analysis, it was seen that the studies aimed at closing the gap in income distribution especially after 80 gave successful results, but socio-economic policies implemented within the scope of struggle against poverty gave results at relative levels. In general, an evaluation was made within the framework of the findings and it was observed that there was a relative success in the areas of poverty and income distribution.
\end{abstract}

\section{STRUCTURED ABSTRACT}

Income distribution inequality and poverty are among the most common problems of all countries of the world, regardless of whether they are developed or developing country. Countries apply various development policies to distribute their income fairly to all segments of society and thus to ensure poverty reduction. There is a strong relationship between income distribution inequality and poverty. As income inequality increases, so does impoverishment. For this reason, it is not possible to consider income inequality and poverty concepts

Turkish Studies - Economics, Finance, Politics

Volume 14 Issue 3, 2019 
separately. To define these concepts, income distribution refers to the share of national income obtained in a given period for all classes of society and poverty refers to the proportion of households that are below $60 \%$ of the average national income (İzgi \& Alyu, 2018: 988). In line with other countries in the world in Turkey, income inequality and poverty have become one of the topics widely discussed since the 1980s. Negative perceptions and expectations that exist in society in general show that these issues will remain on the agenda.

The purpose of this study, "In the 2000s, economic many areas strides performs Turkey in many countries of the world that has progressed towards becoming a fairer country in income distribution which began as a major problem and that it is important how the fight against poverty" is examined. In this context, "Turkey Is income inequality and position in the overall successful enough in the fight against poverty and countries of the world during the last 20 years what?" Question will be investigated.

In this context, income distribution; It can be defined as the distribution of national income obtained in a country within a certain period of time between individuals, groups, production factors or regions in the country. However, it is necessary to obtain different sample groups when analyzing income distribution for both countries and countries. Otherwise, comparison will be difficult. For instance, income types (wage, interest, journal, etc.) and gender analysis, which are among the income distribution findings, vary according to age, time period or regions. Therefore, which results of the analysis correctly reflect the distribution of income is another issue that needs to be examined (Burkhauser et al., 1997: 20).

It is wrong to consider income distribution injustice only as an economic-based problem. Income distribution injustice is also a problem with social foundations. It is wrong to consider income distribution injustice only as an economic-based problem. Income distribution injustice is also a problem with social foundations. This problem can lead to social disintegration (Üzümcü and Korkat, 2014; 138). After World War II, countries made significant progress in terms of income distribution. Especially in the 1970s with the Gini coefficient method approaching zero point in many countries, the oil crisis after 1970 , the development of the understanding of capitalist and globalizing economy, political crises in many reasons such as income distribution inequality has started to increase again. In Turkey, influenced by these negative developments in the world, after January 24th decisions, especially import substitution transition to understanding based on imports from the economic understanding and global marketing network to keep pace with the moves it has led countries against the consequences on income inequality (Danişoğlu, 2004: 160).

Poverty, which is one of the biggest problems of income distribution injustice in economies, is the inability to meet the physiological needs of the individual. The concept of poverty can be evaluated in two different ways. From a narrow perspective, poverty can be thought of as an individual dying of starvation or lack of a place to live. To be defined from a broad point of view, even if they have the opportunity to meet the needs of the individual such as food, shelter

Turkish Studies - Economics, Finance, Politics

Volume 14 Issue 3, 2019 
and dressing, it is a lower standard of living than the general population (Üzümcü and Korkat, 2014; 139).

The causes of poverty vary according to countries, regions, gender, and characteristics of households. The first of these reasons, which are generally evaluated from two perspectives, consists of those who argue that the country is realized due to socio-economic structural problems. The second view states that the personal ability and skills of the people, determination to work and discipline, personal decisions and luck, such as the elements of the individual himself is due to express (SSenses, 2006: 145-146).

In addition to these general reasons mentioned above, macro factors such as poverty, increase in population, inflation, economic crisis, economic growth rate, lack of savings and investment, unemployment, political reasons and effects of globalization and micro features such as households, gender, education and migration It can be said to occur in (Marasal1, 2018: 40).

Since it is almost impossible to achieve absolute justice, it is not an equitable distribution of income. But the aim is that the gap between the rich and the poor is very clear and the gap is not too deep. In other words, at a reasonable level, it can be expressed as the fact that each sector receives a share of national income in proportion to its own contribution to production.

The deterioration in the structure of income distribution has important consequences in many economic aspects. For example, according to Keynes, the deterioration in income distribution is against the workers who have a very high marginal consumption tendency, which leads to a decrease in total demand and thus a decrease in production and employment. The opposite is also valid (Alkin, 1995: 141). However, some economists believe that the determination of savings trends by consumption distribution as well as consumption will indirectly affect the economic growth rate (Çalışkan, 2010: 102).

From a general point of view, the disruption in income distribution has caused a chain effect on people's livelihoods, unhappiness, social unrest, further deterioration of political stability, increase of young unemployed people, decrease in social welfare, migration to rich countries and easy implementation of terrorist interventions (Karluk, 2005: 70).

Many different methods can be applied to determine the status of income distribution in the country. These methods can be listed as Gini coefficient, Lorenz curve, Theil index, Percentage share analysis and finally Pareto Optimum, defined as the resource allocation situation in which it is not possible to improve the status of one of the producers, consumers and factor holders without worsening the status of one of the producers.

Considering statistical data of income inequality started when analyzed, and Turkey, from Gini Coefficient in light of the data of the analysis coefficient in 2002 was seen as a decrease in general until 2014 , relative in the sequel enters again rise with the beginning of the decline of the economic and political stability. It is observed that inequality in income distribution decreased compared to 2002 and a

Turkish Studies - Economics, Finance, Politics

Volume 14 Issue 3, 2019 
relative improvement occurred. When the P80 / P20 ratio is considered, it has been realized as 9.5 times in 2002 and follows a course that can be considered parallel to the trend followed by the Gini coefficient and shows a decrease until 2014 in general, although there are years in which it increases. As of the end of 2017, the P80 / P20 ratio was 7.4 times. Of course, since this coefficient represents the ratio of the share of the richest $20 \%$ of the national income to the share of the poorest $20 \%$ of the national income, the decrease in this ratio shows that income inequality has decreased. When the twenty percent shares are examined, it is seen that there is no significant change in the rates of the 2nd, 3rd and 4th grades, and the ratios of the poorest and richest classes have changed relatively more. The analysis of the obtained data, Turkey takes its place in the middle row while the last row in comparison with all world countries compared with developed countries in income disparity. In addition to Turkey, the issue of income distribution is located in a position to fail. Therefore, the issue of income inequality gives the signal that will create major problems for Turkey in the coming years.

In conclusion, this study income for the period after 2000 in Turkey, inequality and poverty statistics have been analyzed is the precipice on the findings on income distribution experienced in the aftermath of light 80 is closed and the fight against poverty behalf implementation of socio-economic policies, is seen to result in relative level. Significant increases in the share of the poorest and the middle class from national income have been observed and a significant decrease has been experienced in the number of poor. Although the current situation cannot be considered satisfactory at the international level, the developments achieved over the years are promising.

The government can intervene in income distribution with the name of "redistribution ina to the wages, rent, interest and profit shares which are the prices of production factors by taxation method. This intervention is higher than the high-income factor and lower or lowerincome taxes. In terms of expenditure, the state is injustice in the distribution of income by spending more taxes on high-income groups to lower-income groups, or transferring more resources to pension, scissors can provide narrowing.

The issue of income distribution inequality becomes a problem not only for underdeveloped countries but also for developing countries. In addition, the inequality of income distribution increases the impoverishment, indicating that there is no situation that can be solved by the current free market order and non-interventionist state understanding. Considering that income distribution has a more persistent and persistent structure than poverty, the issue of income distribution in the struggle against poverty should not be ignored and it should be struggled together.

Although economic growth is seen as a solution in the fight against poverty, it is not enough. In order to ensure stability in many macroeconomic indicators, particularly in education, health and transportation, economic growth should be supported by various policies. In addition to increasing income levels, improvements should be made in terms of working hours, personal rights and safe work

Turkish Studies - Economics, Finance, Politics

Volume 14 Issue 3, 2019 
environments, in order to increase social welfare and to ensure that individuals reach human living standards. Turkey.

Keywords: Income Distribution, Income Inequality, Poverty,

\section{Giriş}

Gelişmiş veya gelişmekte olduğu fark etmeksizin bütün dünya ülkeleri için en önemli makroekonomik problemlerden biri de gelir dağılımı eşitsizliği ve yoksulluktur. Elde edilen gelirin toplumun tüm katmanlarına adil bir şekilde dağılımı ve yoksul nüfusun azaltılması, kalkınma politikalarının stratejik başlıklarından biri olmuştur. Bu iki değişken birbiriyle ilintilidir. Gelir eşitsizliği arttıkça yoksullaşma da artmaktadır. Dolayısıyla bu iki kavramı birbirinden ayrı düşünmek mümkün değildir. Bu kavramları tanımlamak gerekirse, gelir dağılımı belirli bir dönemde elde edilen ülke gelirinin toplumu oluşturan tüm sınıflara düşen payını, yoksulluk ise ortalama milli gelirin \% 60'1nın altında kalan hane halkının oranını ifade etmektedir (İzgi \& Alyu, 2018:988).

Dünyada her alanda olduğu gibi ekonomik alanda da küreselleşmeyle birlikte küresel iktisadi gelir her geçen yıl artmasına rağmen, gelirdeki adaletsiz dağılım yoksulluğun artmasına neden olmaktadır. Yoksulluğun artması ise her ülkede suç oranlarının artması, siyasi istikrarsızlıklar, umutsuz birey sayısındaki artış, güvenlik sorunları gibi büyük sosyal problemlerin baş göstermesine sebep olmaktadır. Böylelikle konuya dair paradigma değişirken, konu ekonomik bir sorun olmanın dışında, politik ve sosyal bir sorun olarak da görülmeye başlanmıştır (Abay \& Sezgin, 2018:98).

Türkiye'de dünya kamuoyuna paralel olarak, gelir dağılımı eşitsizliği ve yoksulluk 1980'li yıllardan itibaren sıkça tartışılan konulardan biri haline gelmiştir. Toplumda genel olarak var olan negatif alg1 ve beklentiler, bu konuların gündemdeki yerini koruyacağını göstermektedir.

Bu çalışmanın amacı, “2000’li yıllarda ekonomik birçok alanda atılımlar gerçekleştiren Türkiye'nin birçok dünya ülkesinde önemli bir problem olarak baş gösteren gelir dağılımında daha adil bir ülke olma yolunda ilerleme kaydedip kaydetmediğinin ve yoksullukla mücadelede ne denli başarılı olduğunun" incelenmesidir. Bu bağlamda "Türkiye gelir eşitsizliği ve yoksullaşmayla mücadelede yeterince başarılı $\mathrm{m} 1$ ve genel olarak dünya ülkeleri içerisindeki konumu son $20 \mathrm{y} 1 \mathrm{ll}$ k dönem itibariyle nedir?" sorusu araştırılacaktır.

Bu çalışma dört bölümden oluşmaktadır. Giriş mahiyetinde olan bu birinci bölümün ardından ikinci bölümde konu kavramsal boyutuyla ele alınacaktır. Üçüncü bölümde Türkiye’ye dair gelir eşitsizliği ve yoksullaşma istatistiklerine yer verilip, mevcut durum analiz edilecektir. Ardından seçili ülkelere dair veriler kullanılıp karşılaştırmalı bir analiz yapılacaktır. Bu sayede Türkiye'nin uluslararası düzeydeki konumu tespit edilmeye çalışılacaktır. Son bölüm olan sonuç bölümünde ise elde edilen bulgulara dair genel bir değerlendirmede bulunulup, konuya dair çözüm önerilerine yer verilecektir.

\section{Kavramsal Çerçeve}

Bu bölümde "gelir dağılımı ve yoksulluk" kavramları genel hatlarıyla ele alınıp, ortaya çıkış nedenleri ve ölçüm metotlarından bahsedilecektir.

\subsection{Gelir Dağılımı Kavramı}

Gelir dağılımı, bir ülkede belli bir zaman diliminde elde edilen milli gelirin bireyler, gruplar, üretim faktörleri ya da ülkedeki bölgeler arasındaki dağılımı olarak tanımlanabilmektedir. Ancak gerek ülkelerarası gerekse ülke için gelir dağılımı analizi yapılırken farklı örneklem grupları elde edilmesi gerekmektedir. Aksi takdirde karşılaştırma yapılması zorlaşacaktır. Mesela gelir dağılımı bulgularından olan gelir çeşitleri (ücret, faiz, yevmiye vb.) ile cinsiyet analizi yaşa, zaman dilimine 
veya bölgelere göre farklılık göstermektedir. Bundan dolayı elde edilen analiz sonuçlarının hangisinin gelir dağılımını doğru yansıttığı ayrıca tetkik edilmesi gereken başka bir konu olarak karşımıza ç1kmaktadır (Burkhauser vd.,1997:20).

\subsubsection{Gelir Dağılımı Türleri}

Gelir dağıllımı türleri genel olarak dört ana bölüme ayrılabilmektedir. Bunlar (Kuştepeli \& Halaç, 2004:6-7):

$$
\begin{array}{ll}
\text { - } & \text { Fonksiyonel gelir dağılımı } \\
\text { - } & \text { Kişisel gelir dağılımı } \\
\text { - } & \text { Sektörel gelir dağılımı ve } \\
\text { Bölgesel gelir dağılımıdır. }
\end{array}
$$

Fonksiyonel gelir dağglımı, üretim faktörlerinin üretime yaptıkları katkının yanında milli gelir içindeki payı olarak tanımlanırken; kişisel gelir dağılımı, milli gelirin ülke nüfusu tarafından nasıl paylaşıldığını göstermektedir. Kişisel gelir dağılımında uygulanan yöntem nüfusun \%20’lik dilimler haline getirilip dağıtılması şeklinde yapılmaktadır (Üzümcü ve Korkat, 2014; 138). Sektörel gelir dağglımı, üretim sektörlerinden tarım, sanayi, hizmet ve diğer sektörlerin ülke milli gelirinden aldıkları paylar olarak tanımlanırken; bölgesel gelir dağılımı ise ülkenin farklı bölgelerinde yaşayan nüfusunun milli gelirin ne kadarına sahip oldukları göstermektedir. Bölgesel faklılık oranlarının yüksek olması, farklı sorunlara zemin hazırlayabilmektedir. Özellikle etnik ya da dinsel farklılıklarda varsa ülkenin bölünmesi gibi kötü sonuçlara bile yol açabilir (Üzümcü ve Korkat, 2014; 138). Bu gelir dağılımı türleri, ülkedeki gelir dağılımı hakkında detaylı bilgi vermesine karşın yeterli değildir. Çünkü gelir dağılımının ayrıca yaş, cinsiyet, meslek grupları gibi unsurlarla da incelenmesi gerekmektedir.

\subsubsection{Gelir Dağılımı Eşitsizliği Ölçüm Yöntemleri}

Türkiye'nin de aralarında bulunduğu birçok ülke, çeşitli gelir dağılımı eşitsizliği ölçüm yöntemleri arasından en popüler olan şu dört yöntemi kullanmaktadırlar (Elveren, 2013:36):

- $\quad$ Yüzde paylar analizi,

- $\quad$ Gini katsayısı,

- Lorenz eğrisi ve

- $\quad$ Theil indeksidir.

a. Yüzde Paylar Analizi: Ülke vatandaşlarının kişisel geliri \% 5, \% 10, \% 20 gibi dilimler halinde sinıflandırılarak milli gelirden ne kadar pay aldıkları hesaplanmaktadır. Böylece ülke nüfusunun dilimleri arasındaki gelir farkları ortaya çıkarılmaktadır (Kalaycı vd., 2017:339).

b. Gini Katsayısı: 0 ile 1 arasında değişen değerlerden oluşan katsayı, Şekil 1'de görüldügü üzere Lorenz Eğrisi ile Eş Bölüşüm Doğrusu arasında kalan kavisli bölgenin ABC üçgenine oranlanması ile elde edilmektedir. 0'a doğru yaklaştıkça gelir dağılımında eşitsizliğin azaldığı, 1'e doğru yaklaştıkça eşitsizliğin arttı̆̆1 sonucuna ulaşılmaktadır (Kalaycı \& Öztürk, 2017:155-156). 


\section{Şekil 1: Lorenz Eğrisi}

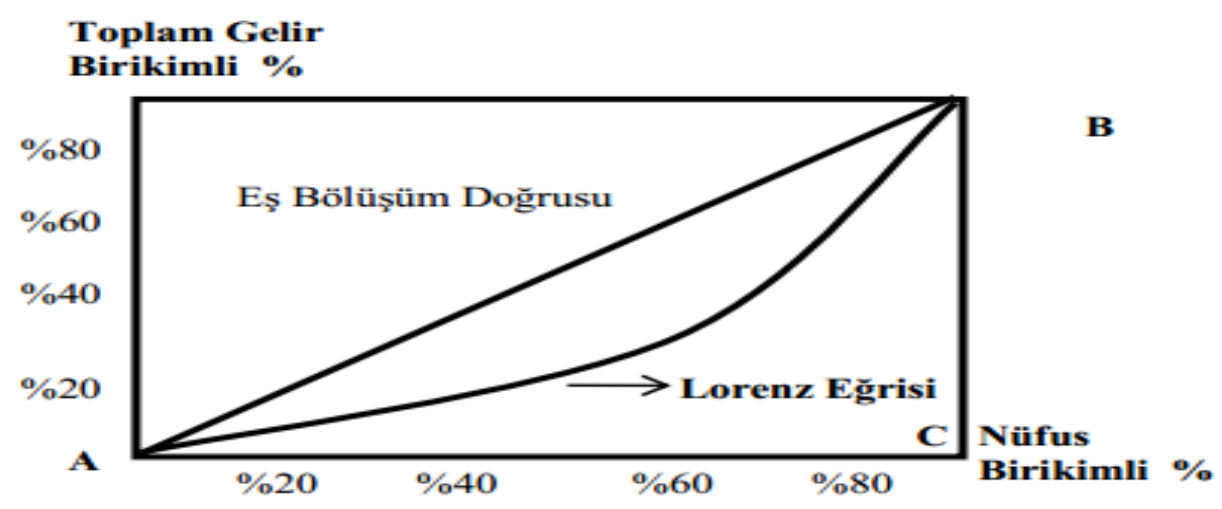

c. Lorenz Eğrisi: Tıpk1 yüzde paylar analizi yönteminde olduğu gibi küçükten büyüğe bir sıralama olmakla birlikte Şekil 1'de görüldüğü üzere gelir dağılımında tam bir eşitliğin söz konusu olması Eş Bölüşüm Doğrusu (AB Doğrusu) ile gösterilmektedir. Fakat Lorenz Eğrisi, AB doğrusundan ne kadar uzaklaşırsa eşitsizliğin de o kadar arttığı anlamına gelmektedir (Elveren, 2013:37).

d. Theil İndeksi: 0 ile sonsuz arasındaki değerler ile gösterilen indeks, farklı gelir grupları arasındaki uzaklıklara aynı seviyede duyarlılık göstermektedir. İndekse göre, değer büyüdükçe gelir dağılımında adetsizliğin arttığı, değer küçüldükçe adaletsizliğin azaldığı anlaşılmaktadır (Selim vd., 2014:166).

$\mathrm{Bu}$ yöntemlerinin yanında ülkenin yoksulluk oranı da gelir dağılımı analizi açısından önemli bir gösterge olarak kabul edilmektedir. Çünkü yoksulluk oranı analizlerde, gelir eşitsizliği ile arasındaki doğru yönlü bir ilişkiyi göstermenin yanında Gini Katsayısının da tek başına kullanılmasından doğan birtakım sakıncaların kaldırılmasına yaramaktadır. Bu açıdan da analizlerde önemli bir eksikliği ortadan kaldırmaktadır (Acar, 2015:48).

\subsubsection{Gelir Dağılımında Eşitsizliğin Nedenleri}

Gelir dağılımı adaletsizliği, sadece ekonomik temelli bir sorun değil aynı zamanda sosyal temelleri olan bir sorundur. Bu sebeple toplumsal ayrışmalara vb. yol açabilmektedir (Üzümcü ve Korkat, 2014; 138). 2. Dünya Savaşı sonrası ülkeler gelir dağılımı hususunda önemli gelişmeler kaydetmiş̧lerdir. Özellikle 1970'li yıllara kadar Gini katsayısı yöntemi ile birçok ülkede sıfıra yaklaşılma gerçekleşirken 1970 sonrası yaşanan petrol krizi, kapitalist ve küreselleşen ekonomi anlayışının gelişmesi, siyasi krizler gibi birçok sebepten dolayı gelir dağılımında eşitsizlikler tekrar artmaya başlamıştır. Dünyada yaşanan bu olumsuzluklardan etkilenen Türkiye'de, 24 Ocak kararları sonrası özellikle ithal ikameci ekonomi anlayışından ithalata dayalı anlayışa geçilmesi ve küreselleşen pazar ağına ayak uydurma hamleleri, gelir eşitsizliği konusunda ülke aleyhine neticeler doğmuştur (Danışoğlu, 2004:160).

Bütün faktörler ele alınarak değerlendirildiğinde ülkeden ülkeye farklılık gösterebilen yerel sebepler haricinde genel olarak gelir dağılımı eşitsizliğine sebep olan unsurlar şu şekilde sıralanabilir (Acar, 2015: 48):

- $\quad$ Servet dağılımı,

- Ülke ekonomisindeki istikrar ve büyüme durumu,

- $\quad$ Emeğin dağlımı,

- Demografik durum,

Turkish Studies - Economics, Finance, Politics

Volume 14 Issue 3, 2019 


\section{- $\quad$ Küreselleşme ve \\ - Göç.}

\subsection{Yoksulluk Kavramı}

Yoksulluk, bireyin fizyolojik ihtiyaçlarını karşılayamaması durumudur. Yoksulluk kavramını iki farklı yönden değerlendirebiliriz. Dar bir bakış açısıyla yoksulluk, bireyin açlıktan ölme ya da barınacak bir yerinin olmaması olarak düşünülebilir. Geniş bir bakış açısıyla tanımlanacak olursa, bireyin gıda, barınma, giyinme vb. gibi ihtiyaçlarını karşılama imkânları olsa bile toplumun genelinden daha düşük düzeyde bir yaşam standardı olmasıdır (Üzümcü ve Korkat, 2014; 139).

Kısaca yoksulluk kavramı, bireyin ya da halkın hayatını devam ettirebilmesi için gerekli asgari ve zaruri ihtiyaçlar olan gıda, giyim ve barınağın karşılanabilmesi ile açıklanmaktadır. Buna ayrıca mutlak yoksulluk da denilmektedir. Mutlak yoksulluk dünyanın hemen her yerinde ortaya çıkmaktadır. Ancak önemli olan bu durumun nüfusa oranlanmasıdır yani nüfusun yüzde kaçının yoksulluk düzeyinde olmasıdır. Ülkelerarası yoksulluk sınırı ise küresel çapta yoksulluk sınırına giren nüfusu tahmin etmede kullanılmaktadır. Bu yüzden dolar cinsinden ifade edilmektedir. Bu duruma 1985 yılında Dünya Bankasının yoksulluk sınırını 370 doların altı olarak belirlemesi örnek gösterilebilir (Todaro, 2000:165-66).

Bununla beraber hane halkının tüketim düzeyi ve bütçe analizleri yapılırken Dünya Bankasının raporlarında düşük gelirli ülkeler için günlük 1 dolar mutlak yoksulluk sınırı olarak hesaplanmaktadır. Bu değer Doğu Avrupa ülkeleri için 2,15 dolar, Orta Asya ülkeleri içinse 4,30 dolar olarak kabul edilmektedir (WB, 2005).

Yoksulluk para cinsinin dışında farklı tanımlamalar ile de ifade edilebilmektedir. Mesela; Hindistan, hayatta kalmak için asgari düzeyde beslenmeyi yoksulluk sınırı kabul ederken; Birleşmiş Milletler Gıda ve Tarım Örgütü (FAO) ile Dünya Sağlık Örgütü (WHO), yoksulluk tanımında bir insanın bir gün içerisinde tüketmesi gereken asgari kalori miktarını (2100 kalori) kullanmaktadırlar. $\mathrm{Bu}$ kriter hala bir çok ülke tarafından uygulanmaktadır (Şenses, 2006).

\subsubsection{Yoksulluk Türleri}

Yoksulluk tanımı yapılırken insanın temin etmesi gereken ihtiyaçlar ele alındığından dolayı bu kapsamda üç farklı yoksulluk türü ortaya çıkmaktadır. Bunlar (Çalışkan, 2010:100-101):

$$
\begin{array}{ll}
\text { - } & \text { Mutlak yoksulluk, } \\
\text { - } & \text { Göreli yoksulluk ve } \\
\text { İnsani yoksulluktur. }
\end{array}
$$

\section{a. Mutlak Yoksulluk}

Mutlak yoksulluk daha önce de bahsedildiği üzere bir insanın biyolojik olarak yaşamını sürdürebilmesi için ihtiyaç duyduğu asgari ve zaruri temel gıda bileşenlerini sağlayabilmesi olarak tanımlanabilmektedir. Bu seviyeyi sağlayamayan kişiler yoksulluk sınırının altında kabul edilip yoksul olarak nitelendirilirken bu seviyenin üstünde bir gelire sahip kişilerse yoksul olmayanlar olarak kabul edilmektedir (Marasalı, 2018:32-33).

$\mathrm{Bu}$ yoksulluk türünün belirlenmesinde iki farklı yöntem uygulanmaktadır. İlki "Temel Gereksinim Yaklaşımı" olup, kişinin hayatını devam ettirebilmesi için asgari gıda, giyim, barınma, sağlık, eğitim gibi ihtiyaçlarının hesaplanması ile oluşmaktadır. İkincisi ise "Minimum Gıda Sepeti" yöntemi olup, bireyin 1 günlük alması gereken kalori miktarının hesaplanması ile değerlendirilmektedir. $\mathrm{Bu}$ yöntem özellikle gelişmekte olan ülkelerin ulusal yoksulluk sinırını belirlerken kullandıkları gıda yoksulluğu yöntemi olarak önem arz etmektedir. Bu yöntem için de 
detaylı bir analiz yapılması için üç farklı hesaplama yapılmaktadır. Bunlar temel ihtiyaçların maliyeti, gıda enerjisi ve gıda paylaşım yöntemi hesaplamalarıdır (Kayalıdere \& Şahin, 2014:67).

\section{b. Göreli Yoksulluk}

Göreli yoksulluk, kişinin asgari temel ihtiyaçlarının karşılanmasının yanında toplumdaki diğer bireylerin durumuna göre de yoksulluk hesaplamasının yapıldığı kavramdır. Bu yoksulluk türünde ülkedeki kaynakların yetersizliğinden dolayı kişisel ihtiyaçlarının temin edilememesi, bireyi yoksulluk seviyesine dâhil edebilmektedir. Bu yüzden bu yoksulluk türüne göre, insan ihtiyaçları ve yoksulluk durumu yöresel, mekânsal, zamansal ve kültürel farklılıklar dolayısıyla standart bir hesaplama ile gerçekleştirilememektedir (Sapancalı, 2005:55).

\section{c. İnsani Yoksulluk}

İnsani yoksulluk türü, diğer iki türden daha kapsamlı ve kuşatıcı bir tanım olarak Birleşmiş Milletler tarafından yapılmıştır 1997'de Birleşmiş Milletler Kalkınma Programı (UNDP) tarafından yayınlanan raporda insani yoksulluk; bireyin sıhhatli ve adaletli bir hayat sürmesi için gerekli bütün parasal, iktisadi, sosyal ve kültürel şartlara sahip olması gerektiği özellikle vurgulanmıştır. Bu yaklaşım ile yoksulluğun çok kapsamlı bir kavram olarak gelişmesi, yaşam süresi, eğitim düzeyi ve kamuya ait kaynaklara erişebilme gibi göstergelerin de hesaplamalara dâhil edilmesi, yoksulluk için ülkelerarası karşılaştırma yapılabilmesini sağlayan bir endeksin oluşmasına neden olmuştur (Güneş, 2009:4-5).

Ayrıca yoksulluk farklı bir değerlendirme ile iki yönde değerlendirilebilmektedir. Bunlar kırsal yoksulluk ve kentsel yoksulluktur. Kırsal yoksulluk, genellikle kırsal bölgelerde yerleşik olan toplumun karşılaştığı bir türdür(Üzümcü ve Korkat, 2014; 140). Özellikle toprağı olmayan, tarım işçileri veya küçük köylerde yaşayan halkta karşılaşılan yoksulluk türüdür (Kaptan ve Demirhan, 2014; 142). Toplumun bu kesiminde oluşan kırsal yoksulluk, genel olarak yetersiz kişisel tüketim imkânları, eğitim imkânlarına ulaşım zorluğu, temiz su, ulaşım vb. hizmetlere ulaşamama gibi eksikliklerin ortaya çıkarttığı bir yoksulluk türüdür. Kentsel yoksulluk ile genelde halkın kentlerde yaşayan kesimi karşılaşır. Kentsel yoksullukta odak noktası yetersiz gelir ve yetersiz bir düzeyde olan tüketim imkânlarıdır. Kırsal yoksulluğun artış yapması sonucu kente göçler ve nüfus artışı gibi problemler ortaya çıkabilmektedir (Üzümcü ve Korkat, 2014; 140).

\subsubsection{Yoksulluğun Nedenleri}

Yoksulluğun nedenleri ülkelere, bölgelere, cinsiyete, hane halkının özelliklerine göre farklılık göstermektedir. Genel olarak iki açıdan değerlendirilen bu nedenlerden ilki, ülkenin sosyo-ekonomik yapısal sorunları dolayısıyla gerçekleştiğini öne sürenlerden oluşmaktadır. İkinci görüş ise insanın kişisel kabiliyet ve beceriler, çalışma azmi ve disiplin, aldığı kişisel kararlar ve şans gibi unsurlarından yani bireyin bizzat kendisinden kaynaklandığını ifade etmektedirler (Şenses, 2006:145-146).

Yukarıda sayılan bu genel nedenlerin yanında yoksulluğun nüfusta meydana gelen artış, enflasyon, ekonomik kriz, ekonomik büyüme hızı, tasarruf ve yatırım yetersizliği, işsizlik, siyasi nedenler ve küreselleşmenin etkileri gibi makro nedenler ile hane halkının özellikleri, cinsiyet, eğitim ve göç gibi mikro nedenlerden de oluştuğu söylenebilmektedir (Marasalı, 2018:40).

\subsubsection{Yoksulluğun Ölçüm Yöntemleri}

Birbirinden farklı birçok endeks ve ölçüm yöntemi ile analiz edilen yoksulluk konusu 1970'lerden sonra araştırılmaya başlanmıştır. Bu yöntemler hem detaylı olarak hazırlanmakta hem de birbirleri ile karşılaştırılabilmektedir (Şenses, 2006:65). Yoksulluk ölçümlerinde ilk belirlenen şey, yoksulluk sınırının tespitidir. Daha sonra hangi yöntemin kullanılacağına karar verilir. Yoksulluk ölçümlerinde kullanılan endeks, ülkelerdeki yoksulluğun seviyesi hakkında bilgi sunarken aynı zamanda bu konu hakkında istatistiksel veriler yardımıyla çözüm yolu üretebilmeyi de sağlamaktadır.

Turkish Studies - Economics, Finance, Politics

Volume 14 Issue 3, 2019 
Yoksulluk ölçüm yöntemleri arasında en kolay ve en çok kullanılan yöntemler şunlardır (Marasal1, 2018:55):

- $\quad$ Kafa Sayım Oranı (Head Count Ratio)

- $\quad$ FGT Endeksi (Foster- Greer- Thorbecke Index)

- $\quad$ Yoksulluk Açığı Endeksi (Poverty Gap Index)

- $\quad$ Bileşik Yoksulluk Endeksleri

\section{a. Kafa Sayım Oranı (Head Count Ratio)}

Kafa Sayım Oranı, yoksulluk sınırının altında yaşayan yoksul nüfusun bütün ülke nüfusuna oranlanması ile elde edilmektedir (Kaynak, 2007:108). Bu yöntem bir oran olduğu için yoksulluk sınırı altındaki yoksul insan sayısı analizlerde dikkate alınmamaktadır. Ayrıca yoksul kesimin kendi aralarındaki gelir dağılımı hakkında bilgi vermediği gibi yoksulluk sınırına yakın birey ile bu sınıra çok uzak bireyi ayırt etmediği için de yetersiz olduğu kabul edilmektedir (Katar, 2017:71).

\section{b. FGT Endeksi (Foster-Greer-Thorbecke Index)}

1984 yılında Foster, Greer ve Thorbecke tarafından geliştirilen bu endeks, adını mucitlerinin baş harfinden almaktadır. FGT endeksine göre yoksulluk, çeşitli alt gruplara ayrılarak ayrı ayrı hesaplanmaktadır. Böylece ilgili endeksler, oluşturulan alt gruplar, sahip oldukları nüfus payları ile ayrı ayrı ağırlıklandırılarak toplanır ve toplam yoksulluk oranı elde edilir. Bu yöntem bu açıdan değişik gruplar hakkında göreceli bilgi sunarak detaylı ve karşılaştırmalı araştırma yapılmasını da sağlamaktadır (Katar, 2017:72).

\section{c. Yoksulluk Açı̆̆ı Endeksi (Poverty Gap Index)}

Yoksulluk açığı endeksi, mevcut yoksulluğun ortadan kaldırılması için ne kadar kaynağa ihtiyacın olduğunu gösteren bir endekstir. Bu ihtiyaçların karşılanması genellikle nakit transferler yardımıyla gerçekleşmektedir. Bu durum ihtiyaç olunan kaynağın belirlenmesi ve istatistiki bilgi sunması açısından önemlidir. Böylece yoksulluk sınırının altında olan bireyler yoksulluktan çıkartılabilmektedir. Fakat bu endeks, yoksulların birbiri arasındaki transferlere karşı duyarsız olması ve yoksullar arasındaki eşitsizliği göz ardı etmesi gibi sebepler dolayısıyla, kafa sayım oranını tamamlayıcı bir endeks olmasına karşın eleştirilmiştir (Beken, 2006:76-77).

\section{d. Bileşik Yoksulluk Endeksleri}

Yoksulluk analizleri günümüze kadar genellikle tüketim ve gelir ölçütleri kullanılarak gerçekleştirilmeye çalışılmıştır. Fakat 1990 yılından sonra UNDP tarafından geliştirilen bileşik yoksulluk endeksine göre yoksulların yaşam standartlarının belirlenmesi hakkında fiziksel, psikolojik veya sosyal birçok kriterin besin, gelir ve tüketim kriterlerine dâhil edilmesi gerektiğini ortaya koymuşlardır (Kabaş, 2010:23).

UNDP'ye göre yoksulluk kavramı, uzun ve sağlklı bir hayat standardından, özgüvene sahip olmaktan, özgür ve başka hayatlara saygı duyma fırsatından yoksun olma durumu olarak tanımlanmaktadır (UNDP, 1997:5). Bu yüzden insani yoksulluk analizinde; ölüm oranı, yaşam beklentisi, bebek ölüm oranı, kötü beslenme, hane halkı reisinin eğitim düzeyi, okur-yazarlık oranı, kişi başına düşen toprak alanı gibi göstergeler önemli refah ve yoksulluk kriterleri olarak kabul edilmektedir (Şenses, 2006:96-97).

\subsection{Gelir Dağılımında Adalet ve Yoksulluğun İktisadi Önemi}

Bütün toplumlarda zengin ve yoksul insanların varlığı dünya hayatının olağan durumudur. Fakat bir toplumda zenginlerin sayısı toplam nüfus içinde çok az olmasına rağmen milli gelirin büyük bir kısmına sahip iseler bu durum insanlık açısından adil ve kabul edilebilir bir durum değildir 
(Yazgan, 1975:29). Günümüzde kapitalist sistemin egemen olduğu toplumlarda adil bir yapıdan ve eşitlikten söz etmek mümkün değildir. Çünkü kapitalizme göre bireyler güçleri nispetinde milli gelir pastasından pay almaktadırlar (Aren, 1989:73).

Gelir dağılımından kasıt, mutlak adaletin sağlanması neredeyse imkânsız olmasından dolayı gelirin eşit dağılımı değildir. Fakat amaç, zengin kesim ile yoksul kesim arasındaki makasın çok açık ve uçurumun çok derin olmamasıdır. Yani makul seviyede, üretime her kesimin kendi katkısı nispetinde milli gelirden pay alması olarak da ifade edilebilir.

Gelir dağılımının yapısındaki bozulmalar iktisadi birçok açıdan da önemli sonuçlar doğurmaktadır. Mesela Keynes'e göre gelir dağılımındaki bozulmanın, marjinal tüketim eğilimi çok yüksek olan işçiler aleyhine olması demek, toplam talebin düşmesine ve dolayısıyla üretim ve istihdamın azalmasına neden olmak demektir. Tersi durumun geçerliliği de söz konusudur (Alkin, 1995:141). Bununla birlikte bazı iktisatçılar, tüketimin yanında tasarruf eğilimlerinin de gelir dağılımı tarafından belirlenmesinin iktisadi büyüme hızını dolaylı olarak etkileyeceği görüşündedirler (Çalışkan, 2010:102).

Gelir eşitsizliği genelde makroekonomik bir sorun olarak kabul edilse de sosyal ve siyasal bir takım sorunların kaynağı olarak da karşımıza çıkmaktadır. Özellikle az gelişmiş ülkelerde gelir eşitsizliğinin yüksek olması düşük kültür ve eğitim seviyesine, nüfusun büyük bir çoğunluğunun yetersiz beslenmesine, sağlık standartlarının çok düşük olmasına neden olmaktadır. Bununla birlikte halkın büyük çoğunluğu sefalet ve yokluk içinde yaşarken belirli bir zengin kesim, gelişmiş ülkelerdeki tüketim tarzlarını taklit ederek hayatlarını suni şekilde idame etmektedirler. Bu gibi toplumlarda gelir eşitsizliği arttıkça hırsızlık, gasp, kapkaç gibi suç oranları artmakta ve toplumun huzur, güven ve barışı bozulmaktadır (Şahin, 2007:580).

Sonuç olarak gelir dağılımındaki bozukluk insanların geçim sıkıntısı çekmesine, mutsuz olmalarına, sosyal huzursuzluk çıkarmalarına, siyasi istikrarın daha da bozulmasına, genç işsizlerin artmasına, toplumsal refahın azalmasına, zengin ülkelere göç edilmesine ve terörist müdahalelerinin kolay uygulanabilmesine zincirleme bir etki ile neden olmaktadır (Karluk, 2005:70).

\section{Türkiye'de Gelir Eşitsizliği ve Yoksulluk Göstergelerinin Analizi}

\subsection{Gelir Eşitsizliği Analizi}

Gini katsayısı, Lorenz eğrisi, Theil endeksi, Yüzde paylar analizi ve son olarak, toplumdaki üretici, tüketici ve faktör sahiplerinden birinin durumunu kötüleştirmeden diğerlerinin durumunu iyileştirmenin mümkün olmadığ1 kaynak tahsisi durumu olarak tanımlanan Pareto Optimumu gibi yöntemler gelir dağılımı eşitliğini ölçmede kullanılan yöntemlerdir. Tablo 1'de Türkiye İstatistik Kurumu (TÜIK) ve Dünya Bankası (WB) tarafından alınan veriler 1şığında Türkiye'de 2002-2017 y1llarına ait Gini katsayıs1, P80/P20 oran1 ve Siralı Yüzdeler dilimleri gösterilmektedir. Daha önce de bahsedildiği gibi Gini katsayısı, Lorenz eğrisine bağlı olarak hesaplanmakta olup 0 ile 1 arasında bir değer almaktadır. Değerin sıfıra yaklaşması gelir eşitsizliğinin azalmasını gösterirken değerin bire yaklaşması gelir eşitsizliğinin artması anlamına gelmektedir. P80/P20 oranı ise aslında yüzde paylar analizinin ta kendisi olup en yüksek gelire sahip \% 20 ile en düşük gelire sahip \% 20'lik grubun birbirine oranlanmasını ifade etmektedir. Son olarak sıralı yüzdeler dilimleri ise hane halkının kullanabilir geliri üzerinden hesaplanmaktadır. Hane halklarının kullanılabilir geliri öncelikle küçükten büyüğe sıralanmakta daha sonra \% 20'lik paylara bölünerek 5 gruba ayrılmaktadır. Dolayısıyla ilk \% 20'lik grup geliri en düşük grubu gösterirken son \% 20'lik grup da gelir seviyesi en yüksek grubu göstermektedir. 
Tablo 1: Gelir Eşitsizliği Göstergeleri

\begin{tabular}{|c|c|c|c|c|c|c|c|}
\hline \multirow{2}{*}{ Yillar } & \multirow{2}{*}{$\begin{array}{c}\text { Gini } \\
\text { Katsayısı }\end{array}$} & \multirow{2}{*}{$\begin{array}{c}\text { P80/P20 } \\
\text { Oranı }\end{array}$} & \multicolumn{5}{|c|}{ Yüzde 20'lik Gruplar } \\
\hline & & & İlk \%20 & İkinci \% 20 & Üçüncü \%20 & Dördüncü \%20 & Son \% $2^{(1)}$ \\
\hline 2002 & 0,414 & 9,5 & 5,8 & 10,1 & 14,8 & 21,6 & 47,7 \\
\hline 2003 & 0,422 & 8,1 & 5,5 & 10,0 & 14,6 & 21,5 & 48,4 \\
\hline 2004 & 0,413 & 7,7 & 5,4 & 10,1 & 15,2 & 22,4 & 47 \\
\hline 2005 & 0,426 & 7,3 & 5,2 & 10,0 & 14,8 & 21,7 & 48,3 \\
\hline 2006 & 0,403 & 8,1 & 5,8 & 10,5 & 15,2 & 22,1 & 46,5 \\
\hline 2007 & 0,387 & 7,1 & 6,4 & 10,9 & 15,4 & 21,8 & 45,5 \\
\hline 2008 & 0,386 & 7,1 & 6,4 & 10,9 & 15,4 & 22,0 & 45,3 \\
\hline 2009 & 0,394 & 7,4 & 6,2 & 10,7 & 15,3 & 21,9 & 46,0 \\
\hline 2010 & 0,380 & 6,9 & 6,5 & 11,1 & 15,6 & 21,9 & 44,9 \\
\hline 2011 & 0,383 & 7,0 & 6,5 & 11,0 & 15,5 & 21,9 & 45,2 \\
\hline 2012 & 0,382 & 6,9 & 6,5 & 11,0 & 15,6 & 22,0 & 45,0 \\
\hline 2013 & 0,382 & 6,8 & 6,6 & 10,9 & 15,4 & 21,8 & 45,2 \\
\hline 2014 & 0,379 & 6,9 & 6,5 & 11,0 & 15,6 & 22,2 & 44,7 \\
\hline 2015 & 0,386 & 7,2 & 6,3 & 10,9 & 15,5 & 22,0 & 45,3 \\
\hline 2016 & 0,396 & 7,4 & 6,3 & 10,6 & 15,2 & 21,6 & 46,3 \\
\hline 2017 & 0,400 & 7,4 & 6,3 & 10,6 & 15,1 & 21,4 & 46,7 \\
\hline
\end{tabular}

(1) Hane halkları kullanılabilir gelirlerine göre küçükten büyüğe doğru sıralanarak 5 gruba ayrıldığında; "İlk yüzde 20'lik grup" geliri en düşük olan grubu, "Son yüzde 20'lik grup" ise geliri en yüksek olan grubu tanımlamaktadır.

Kaynak: (TÜIK, WB)

Türkiye'ye ait gelir eşitsizliği göstergelerinin yer aldığı Tablo 1'de, Gini katsayıları analiz edildiğinde 2002'den 2014 yılına kadar genel olarak düşüş gerçekleşmekte olup, görece ekonomik ve siyasi istikrarın gerilemeye başlamasıyla birlikte tekrar artış eğilimine girmektedir. Gelir dağılımında 2002 yılına kıyasen eşitsizliğin azaldığı, nispi bir iyileşmenin gerçekleştiği görülmektedir.

P80/P20 oranı ise 2002 yılında 9,5 kat olarak gerçekleşmiş ve Gini katsayısının izlediği trende paralel sayılabilecek bir seyir izleyip, arada artış gösterdiği y1llar olsa da genel olarak 2014 y1lına kadar düşüş göstermektedir. 2017 y1lı sonu itibariyle P80/P20 oran1 7,4 kat olarak gerçekleşmiştir. Tabi bu katsayının en zengin \% 20'lik grubun milli gelirden aldığı payın, en yoksul \% 20'lik grubun milli gelirden aldığı paya oranını ifade ettiğinden, bu oranda gerçekleşen azalışlar gelir eşitsizliğinin azaldığını göstermektedir. Yüzde yirmilik paylar incelendiğinde 2., 3. ve 4. sınıflara ait oranlarda ciddi bir değişim olmadığı, en yoksul ve en zengin sınıfa ait oranların nispeten daha fazla değiştiği görülmektedir.

Türkiye'de 70'li, 80'li ve 90'lı yıllarda 0,50 dolaylarında seyreden Gini katsayısı ve 20 katlar civarındaki P80/P20 oranı, gelir eşitsizliği olgusunu ciddi tartışmaların odağı haline getirirken, 2000'li yıllarda uygulanan sosyal politikalarının etkisiyle göstergelerde belirgin iyileşmeler sağlanmış ve yeterli olmasa da olumlu sonuçlar elde edildiği söylenebilmektedir. Son 3 yıldaki konjonktürel gerileme dikkate alınmazsa 2002 yılına kıyasen en zengin sınıfın milli gelirden aldığ 1 pay 2014 verilerine göre yaklaşı \% 3 oranında azalış göstermiş ve bu oran diğer sınıfların gelirden aldığı payı yükseltmiştir. 
Grafik 1: Gini Katsayıs1 (2006-2016)

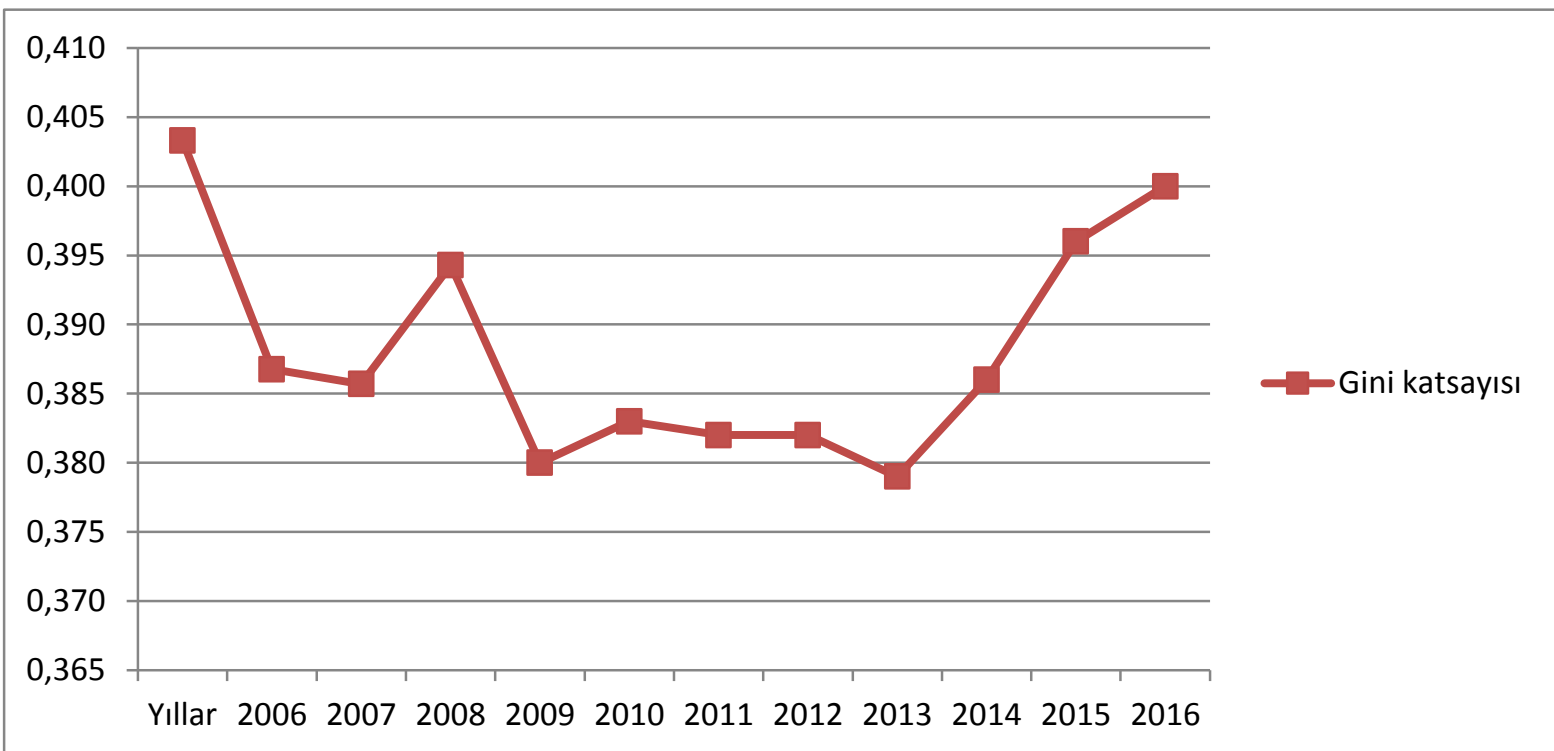

Not: Grafik yazar tarafından Tablo 1'de yer alan veriler kullanılarak oluşturulmuştur.

Gini katsayısının grafiksel gösterimi Grafik 1'de yer almaktadır. Eğrinin 2014 yılına kadar negatif bir seyir izlediği görülmektedir. 2008 yılında başlayan küresel kriz, gelir eşitsizliği katsayısını dönemsel olarak arttırsa da genel trend azalış yönünde gerçekleşmiştir. 2014 yılı sonrasında ise yukarıda da ifade edildiği üzere ekonomik göstergelerde meydana gelen bozulma Gini katsayısının artış göstermesine neden olmuştur.

Grafik 2: P80/P20 Oranı (2006-2016)

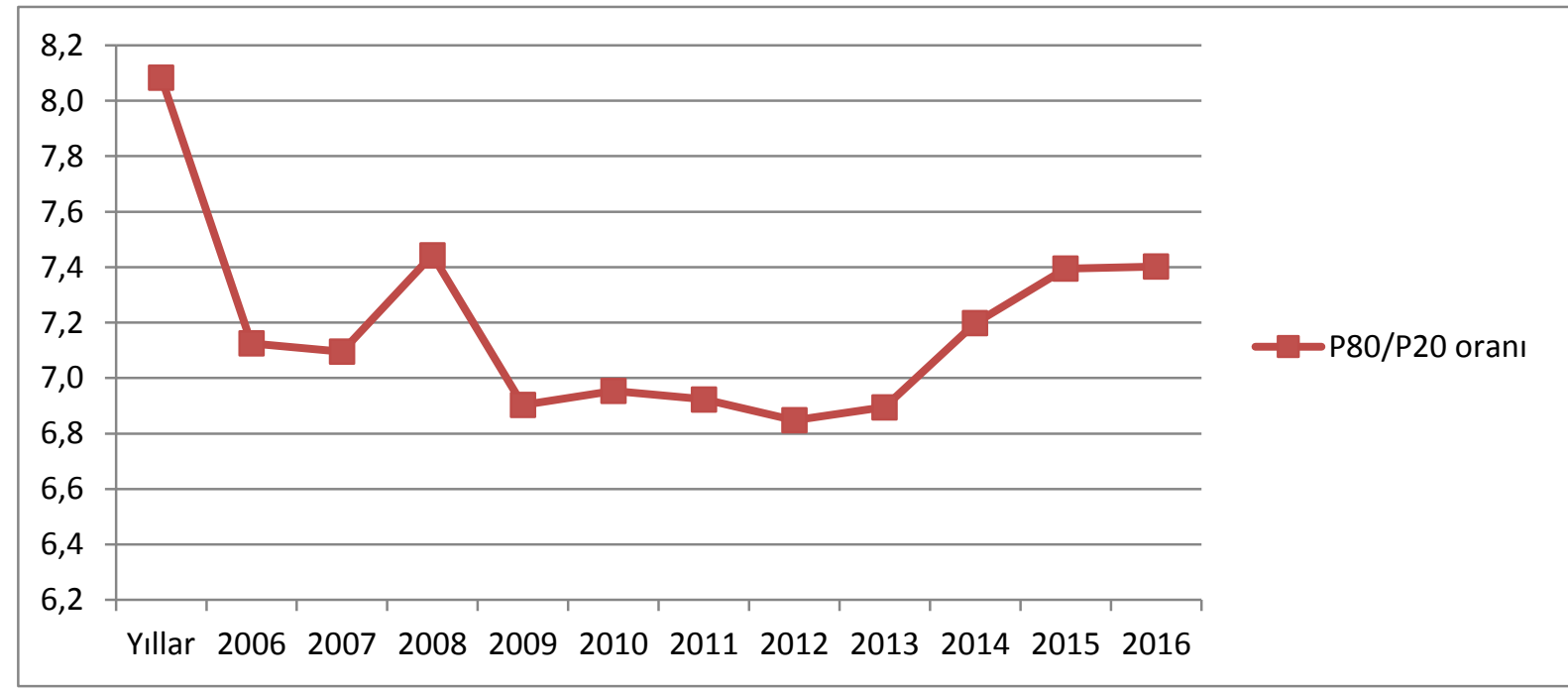

Not: Grafik yazar tarafından Tablo 1'de yer alan veriler kullanılarak oluşturulmuştur. 
2006-2016 yılları arasında gerçekleşen P80/P20 oranının grafiksel gösterimini ifade eden Grafik 2, bu oranın yıllar içerisindeki trendinin 2008 yılı hariç 2014 yılına kadar düşüş yönünde gerçekleştiğini göstermektedir. Ekonomik ve siyasi istikrarın yeterince sağlanamadığı yıllarda en zengin \% 20'lik grubun milli gelirden aldığı payı arttırdığı ve buna mukabil en yoksul \% 20'lik grubun ise payının azalış gösterdiği söylenebilir.

Bir ülkenin gelir eşitsizliği hakkında durum analizinin yapılmasının en iyi yöntemlerinden biri de özellikle gelişmiş ülkeler ile gelir dağılımı verilerinin karşılaştırılmasıdır. Fakat bu karşılaştırmanın sağlıklı bir şekilde yapılmasına engel olan bazı durumlar ortaya çıkmaktadır. Mesela her ülkede yapılan analizlerde kullanılan yöntemin farklı olması, verilerin farklı yıllara ait olması, kimi ölçme yöntemlerinde nüfus baz alınırken kimisinde ise gelir ya da harcamanın baz alınması gibi sebeplerden dolayı tam anlamıyla bir karşılaştırma yapılamamaktadır. Bu sorunun çözümünde en tutarlı veri setleri arasından yer alan Dünya Bankası'nın (WB) hazırladığı veri seti kabul edilmektedir. Bu yüzden Türkiye'nin gelir dağılımı hakkında diğer ülkeler ile anlamlı bir karşılaştırma yapılabilmesi için bu çalışmada WB ve TÜiK verileri kullanılmıştır. Grafik 3'te Türkiye'nin gelir dağılımı konusunda dünyadaki yeri Gini katsayısı ile karşılaştırmalı olarak gösterilmektedir.

Genellikle 2015-2016 y1llarına ait en güncel verilerin bulunduğu Grafik 3 incelendiğinde, Gini katsayısı en yüksek olan ülke Güney Afrika iken, katsayısı en düşük olan ülkenin yani gelirin en adil dağıldığı ülkenin ise pek çok sosyo-ekonomik göstergede olduğu gibi İskandinav ülkelerinden biri olan Norveç olduğu görülmektedir. Seçili ülke grubunda Gini katsayısı en yüksek ülkelerden biri olan Türkiye, Güney Afrika, Meksika ve Peru'dan sonra gelmektedir. Görece düşük nüfuslu gelişmiş ülkelerin Gini katsayısı 0,20 - 0,30 bandında yer alırken, diğer gelişmiş ve gelişmekte olan ülkeler genel olarak $0,30-0,40$ aralığında yer almaktadır. Dünyanın en büyük ekonomisine sahip olan ABD'nin ise Türkiye'ye yakın bir katsayıya sahip olması ilgi çekici sonuçlardan biri olarak göze çarpmaktadır.

Grafik 3: Seçili Ülkeler Gini Katsayısı

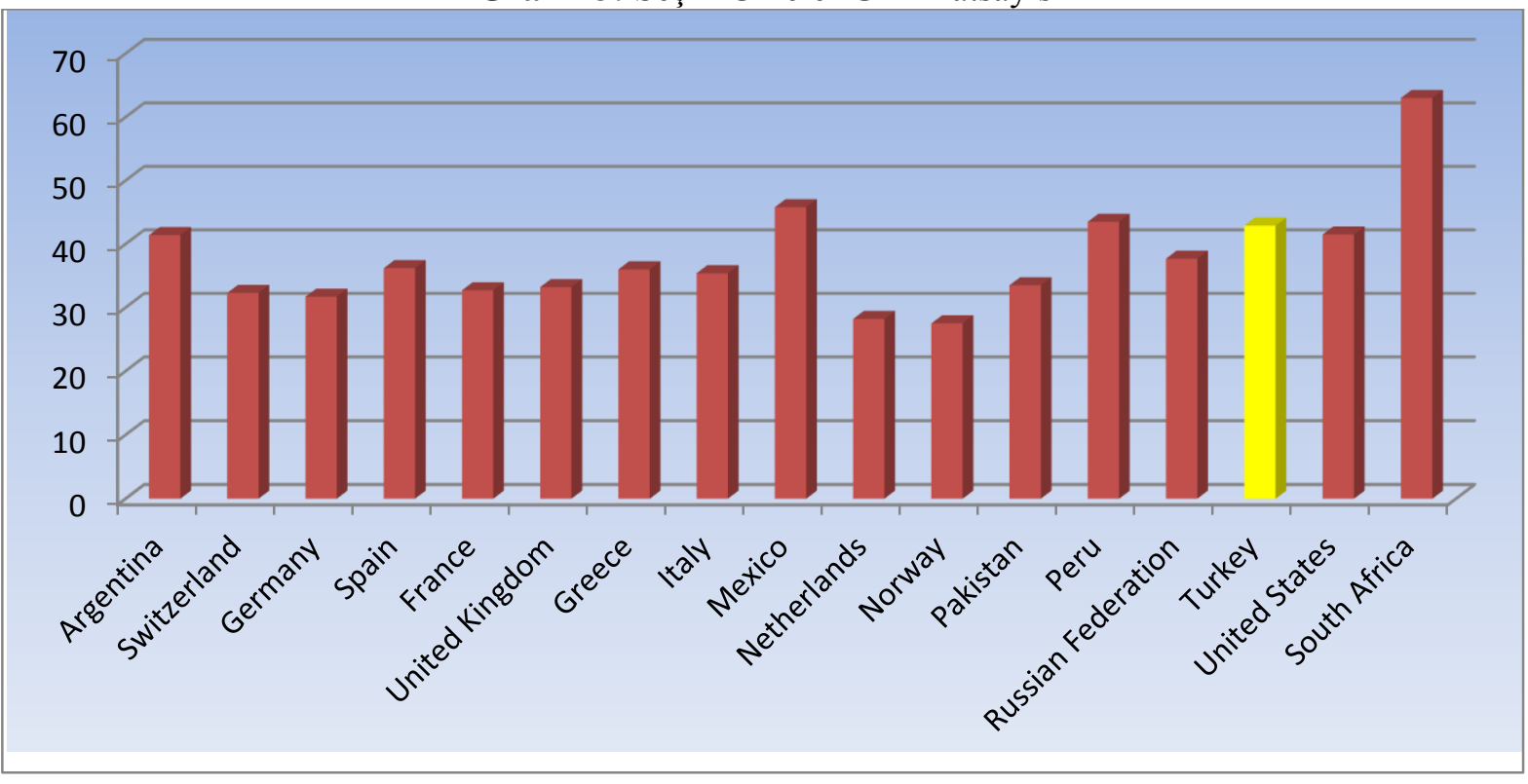

Not: Her ülke için farklı yıllara ait en güncel veriler kullanılmışır.

Kaynak: (WB, TÜİK)

Turkish Studies - Economics, Finance, Politics

Volume 14 Issue 3, 2019 
Analiz neticesinde Türkiye, gelir dağılımı adaletsizliğinde gelişmiş ülkeler ile kıyaslandığında son sıralarda yer alırken bütün dünya ülkeleri ile kıyaslandığında orta sıralarda yerini almaktadır. Buna ilaveten Türkiye, Grafik 3’te görüldüğü üzere gelir bölüşümü hususunda da başarısız bir konumda yer almaktadır. Bundan dolayı gelir dağılımı eşitsizliği konusu, Türkiye için gelecek yıllarda büyük sorunlar oluşturacağı sinyalini vermektedir.

\subsection{Yoksulluk Analizi}

İlki "2002 Yoksulluk Araştırması” adıyla TÜïK tarafından yapılan ve yoksulluğun düzeyini ölçen çalışmalarda, son yıllarda artış gözükse de yeterli seviyede değildir. Buna rağmen 2007 yılında yine TÜIK tarafından yapılan "2006 Yoksulluk Araştırması" bu alanda yapılan en iyi çalışmalardan biri olarak kabul edilmektedir.

Tablo 2'de TÜİK tarafindan yapılan "Gelir ve Yaşam Koşulları Araştırması'na" göre eşdeğer hane halk1 kullanılabilir medyan gelirinin \% 50'si dikkate alınarak belirlenen 2006 - 2017 y1llarına ait yoksulluk verileri yer almaktadır. Tablo incelendiğinde, 2006 yılında yoksulluk sinırı 2.351 TL iken bu sınırın altında yer alan kişi sayısının toplam nüfus içerisindeki payı \%18,6 olarak görülmektedir. Yıllar ilerledikçe yoksulluk oranı, 2008-2009 küresel krizinin Türkiye'yi etkilediği ve ekonomik daralmanın yaşandığı dönem hariç hep düşüş göstermiştir. Dolayısıyla 2017 y1lına bakıldığında yoksulluk oranının \% 13,5'e kadar düştüğü ve yoksul nüfusun yaklaşık olarak \% 5 oranında azaldığ1 görülmektedir. Yoksulluk açığı oranı ise 2006 yılında 31,7 iken 2017 yılına gelindiğinde 22,6'ya kadar düşmüştür.

Tablodaki veriler dikkate alındığında Türkiye'nin yoksullukla mücadelede nispi bir başarı elde ettiği söylenebilir. Ancak hala yoksulluk sınırının altında yaşayan ciddi bir nüfusun varlığı daha etkin politikaların elzem olduğu sonucunu doğurmaktadır.

Tablo 2: Eşdeğer Hane Halkı Kullanılabilir Fert Gelirine Göre Hesaplanan Yoksul Sayıları,Yoksulluk Oranı ve Yoksulluk Açı̆̆, (2006-2017)

\begin{tabular}{|c|c|c|c|c|}
\hline Yıllar & $\begin{array}{c}\text { Yoksulluk Sinırı } \\
\text { (TL) }\end{array}$ & $\begin{array}{c}\text { Yoksul Sayısı } \\
\text { (Bin Kişi) }\end{array}$ & $\begin{array}{c}\text { Yoksulluk Oranı } \\
(\mathbf{\%})\end{array}$ & $\begin{array}{c}\text { Yoksulluk Açı̆ğ } \\
(\mathbf{1})\end{array}$ \\
\hline $\mathbf{2 0 0 6}$ & 2351 & 12548 & 18,6 & 31,7 \\
\hline $\mathbf{2 0 0 7}$ & 3041 & 11163 & 16,3 & 26,4 \\
\hline $\mathbf{2 0 0 8}$ & 3164 & 11580 & 16,7 & 25,6 \\
\hline $\mathbf{2 0 0 9}$ & 3522 & 12097 & 17,1 & 28,0 \\
\hline $\mathbf{2 0 1 0}$ & 3714 & 12025 & 16,9 & 26,6 \\
\hline $\mathbf{2 0 1 1}$ & 4069 & 11670 & 16,1 & 26,3 \\
\hline $\mathbf{2 0 1 2}$ & 4515 & 11998 & 16,3 & 26,0 \\
\hline $\mathbf{2 0 1 3}$ & 5007 & 11137 & 15,0 & 24,4 \\
\hline $\mathbf{2 0 1 4}$ & 5554 & 11332 & 15,0 & 25,3 \\
\hline $\mathbf{2 0 1 5}$ & 6246 & 11219 & 14,7 & 24,3 \\
\hline $\mathbf{2 0 1 6}$ & 7116 & 11026 & 14,3 & 22,6 \\
\hline $\mathbf{2 0 1 7}$ & 7944 & 10622 & 13,5 & \\
\hline
\end{tabular}

(1) Yoksulluk açığı, yoksulluğun derecesi hakkında bilgi verir. Yoksulluk açığının 100'e yaklaşması, yoksulluğun derecesinin çok fazla olduğunu, küçülmesi ise yoksulluk risk derecelerinin daha az olduğunu ifade etmektedir.

Kaynak: (TÜİK, Yoksulluk İstatistikleri) 
Ulusal istatistiklerin daha fazla anlam ifade edebilmesi ancak uluslararası karşılaştırmalar ile mümkün olacaktır. Dünya Bankası raporlarına göre dünyada yaklaşı 1 milyar kişi günlük $2 \$$ gelirin altında yani aşırı yoksulluk sınırının altında yaşamakta ve bu dünya nüfusunun yaklaşı \% $\% 15$ 'ine tekabül etmektedir. Günlük 5,5 doların altında yaşayanlarda Dünya Bankasının yaptığı yoksulluk tanımlamaları içerisinde yer almaktadır. Bu minvalde uluslararası karşılaştırma yapabilmek adına, seçilen ülke grubuna ait Dünya Bankası'ndan alınan yoksulluk verileri Tablo 3'de yer almaktadır.

Tablo 3: Günlük 5,5 \$ Altında Yaşayanların Nüfus İçerisindeki Yüzdelik Payı

\begin{tabular}{|l|c|c|c|c|c|c|c|c|}
\hline Ülke Adı & $\mathbf{2 0 0 2}$ & $\mathbf{2 0 0 8}$ & $\mathbf{2 0 1 0}$ & $\mathbf{2 0 1 2}$ & $\mathbf{2 0 1 3}$ & $\mathbf{2 0 1 4}$ & $\mathbf{2 0 1 5}$ & $\mathbf{2 0 1 6}$ \\
\hline Arjantin & 44,2 & 14,9 & 11,1 & 8,5 & 8,3 & 9,1 & & 7,8 \\
\hline Ermenistan & 83,5 & 53,6 & 63,4 & 56,5 & 54,6 & 52,3 & 48,3 & 43,5 \\
\hline Brezilya & 40,4 & 28,9 & - & 20,8 & 19,5 & 17,9 & 19,4 & 20,7 \\
\hline Almanya & 1,2 & 0,2 & 0,2 & - & 0,2 & - & 0,2 & - \\
\hline İspanya & - & 1,7 & 2,2 & 2,9 & 3,2 & 2,9 & 3,2 & - \\
\hline Fransa & - & 0 & 0,2 & 0,2 & 0,2 & 0,2 & 0,2 & - \\
\hline Birleşik Krallık & - & 1 & 0,7 & 0,4 & 0,5 & 0,5 & 0,7 & - \\
\hline Yunanistan & - & 1,2 & 2,2 & 6,2 & 7 & 7 & 6,7 & - \\
\hline Endonezya & 89,7 & 84,8 & 77,8 & 73,5 & 71 & 69 & 67 & 62,4 \\
\hline Meksika & 43,3 & 37,5 & 37,1 & 36,4 & - & 40,5 & - & 34,8 \\
\hline Hollanda & - & 0,5 & 0,2 & 0,2 & 0,2 & 0,5 & 0,5 & - \\
\hline Norveç & - & 0,5 & 0,2 & 0,2 & 0,2 & 0,2 & 0,2 & - \\
\hline Polonya & 12,6 & 5,4 & 4,7 & 4,7 & 4,6 & 4,2 & 3,6 & 2,1 \\
\hline Paraguay & 47,4 & 33 & 30 & 23,5 & 20,4 & 19,3 & 20 & 20,1 \\
\hline Rusya & 20,8 & 5,2 & 4 & 2,9 & 2,5 & 2,4 & 2,7 & - \\
\hline İsveç & - & 1 & 1,2 & 1 & 1,2 & 0,9 & 1 & - \\
\hline Tayland & 40,1 & 23 & 17,8 & 13,7 & 11,6 & 10,6 & 7,1 & 8,4 \\
\hline Türkiye & 35 & 16,9 & 15,9 & 13 & 11,4 & 10,5 & 11,5 & 9,9 \\
\hline Ukrayna & 47,3 & 8,3 & 6,1 & 4,1 & 3,3 & 3,6 & 7,8 & 6,4 \\
\hline Dünya & 64,1 & 56,6 & 53,9 & 50,8 & 48,7 & - & 46 & - \\
\hline
\end{tabular}

Not: Hesaplanması ve ülkeden ülkeye ulaşılması zor olan bu veriler, incelenen dönemde bazı ülkeler için kimi dönemlerde hesaplanmadığından tabloya eklenememiştir.

Kaynak: (WB, Yoksulluk Göstergeleri)

Tablo 3 analiz edildiğinde, 2002 yılında Türkiye'de günlük 5,5 doların altında yaşayanların toplam nüfus içerisindeki payı \%35 iken 2016 yılına bakıldığında yaklaşık olarak \%10'a kadar düşmüştür. İncelenen grupta yer alan hemen hemen bütün ülkeler bu alanda ciddi gelişmeler kaydetmiş̧ir. Türkiye, bu grupta yer alan Endonezya, Meksika, Brezilya gibi ülkeler hariç yoksulluk oranı en yüksek ülkelerden biri olarak dikkat çekmektedir. Gelişmiş ülkelerde ekseriyetle bu oran sıfıra yakın çıkmaktadır. Her ne kadar Türkiye \%40 dolaylarında seyreden dünya ortalamasının çok altında görünse de, gelişmiş ve üst-orta gelir grubuna mensup ülkeler ile karşılaştırıldığında, yüksek bir orana sahip olduğu söylenebilir. Ancak yine de Türkiye'nin 2000'li yıllarda yoksullukla mücadelede azımsanmayacak bir iyileşme sağladığını söylemek mümkündür.

\section{Sonuç ve Öneriler}

Bir ülkede toplumsal amaçların başında yer alan sosyal barışın sağlanması ve korunması hususunda en önemli etken şüphesiz gelir dağılımının adil olmasıdır. Bu şartın sağlanmasında ise 
asgari gelir düzeyinin tatmin edici belli bir seviyenin altında olmaması ve farklı gelir grupları arasında derin uçurumların oluşmaması gelmektedir. Bununla birlikte kapitalist ve küresel sistemin içinde gelir dağılımında adaletin tesisi kendiliğinden gerçekleşmediği için "sosyal devlet" olma ilkesi gereği hükümetlerin gelir dağılımına müdahale etmesi gerekmektedir.

Gelir dağılımında adaletsizlik, ekonomilerde olumsuz neticeler doğurmasının yanında sosyal, siyasal ve toplumsal açıdan da negatif neticeler meydana getirmektedir. Özellikle sosyal ve sınıfsal gerginlik unsurlarının başında gelir dağılımı eşitsizliği gelmektedir. Dağılımdaki bu sorun kısa dönemde üretimin taraflarını ilgilendiren bir sorun olmakla birlikte uzun dönemde politika yapıcılarının da sorunu olmaktadır. Adaletsiz dă̆glım iktisadi büyümenin unsurları açısından ele alındığında ise tüketim bileşenlerine, tasarruf miktarına ve yatırım kanallarına etkisi ile büyüme analizlerine dâhil edilmesi geren bir faktör olmaktadır. Mesela sürdürülebilir bir büyümenin şartlarından olan üretken alana yapılacak yatırımın, gelir dağlımdaki adaletsizlikten dolayı spekülatif amaçlı rant alanlarına yapılması büyümeyi olumsuz etkileyecektir. Bu yüzden gelişmekte olan ülkeler başta olmak üzere bütün ekonomilerde politika yapıcılarının adil gelir dağılımı konusunda, tamamen piyasa şartlarının neticesine göre hareket etmek yerine planlarında bu adaleti sağlayan mekanizma üzerinde dikkatle durmaları önem arz etmektedir.

Gelir dağılımı adaletsizliği aynı zamanda yoksulluğu da meydana getirmektedir. Asgari ve zaruri en düşük hayat düzeyine sahip olabilmek için gerekli ihtiyaçların karşılamaması olarak tanımlanabilen yoksulluk; sosyal dışlanma, öğretilmiş acziyet, anomi veya yabancılaşma gibi sosyolojik kavramların türetilmesine de neden olmuştur (Erdem, 2009). Çünkü yoksulluğun artması sosyal ve toplumsal huzursuzluğun artmasına, yoksulluk sınırında düşük gelire sahip olunsa dahi zamanla toplumsal barışın ortadan kalmasına, hırsızlık, gasp gibi suçlar başta olmak üzere birçok ahlaki düzenin de bozulmasına neden olacaktır (Akın, 2015:21).

Gelir dağılımı konusu Türkiye'de Cumhuriyet tarihinden günümüze üzerinde konuşulan bir konudur. Özellikle 1980'li yıllardan sonra daha eşitsiz bir dağılımın mevcut olması dikkat çekmektedir. Bunun sebeplerinin başında ise o yıllarda köy-kent ayrımının daha şiddetli olması, nüfusun büyük bir kısmının tarımda istihdam edilirken düşük emek verimliliğine sahip olması, mevcut tarım topraklarının iç bölüşüm eşitsizliği ve dengesizliği gelmektedir. 1987 yılından sonra ise iç ticaret hadlerinin tarım aleyhine dönmesinin yanında uygulanan politikaların sonucu olarak ücretli-maaşlı kesimin reel gelirlerinde meydana gelen azalma onları alt gelir grubuna sokmuştur.

Bu çalışmada Türkiye'de 2000 sonrası döneme ait gelir eşitsizliği ve yoksulluk istatistikleri analiz edilmiş olup elde edilen bulgular 1şığında 80 sonrası dönemde yaşanan gelir dağılımındaki uçurumun kapatıldığ 1 ve yoksullukla mücadele adına uygulanan sosyo-ekonomik politikaların, nispi düzeyde sonuç verdiği görülmektedir. En yoksul sınıf ile ve orta sınıfin milli gelirden aldığı payda önemli oranda artışlar saptanmış ve yoksul sayısında önemli bir düşüş yaşanmıştır. Mevcut durum her ne kadar uluslararası düzeye göre tatmin edici görülemese de yıllar içerisinde kaydedilen gelişmeler umut verici niteliktedir.

Gelir dağılımına devlet, vergilendirme yöntemiyle üretim faktörlerinin fiyatları olan ücret, rant, faiz ve kâr paylarına "yeniden dağılım" adıyla müdahale edebilmektedir. Bu müdahale yüksek gelir elde eden faktörden daha yüksek, düşük gelir elde eden faktörden ise daha düşük oranda vergi alınması ya da hiç alınmaması şeklindedir. Devlet, harcama hususunda da yüksek gelir gruplarından aldığ 1 vergileri düşük gelir grubuna daha çok harcayarak ya da transfer harcamaları denilen emekli, dul, yetim, işsizlik maaşlarına, burslar, sosyal yardımlaşma ve dayanışma fonlarına, sağlık ve eğitim harcamalarına daha fazla kaynak aktarma ile gelir dağılımı adaletsizliğindeki makasın daralmasını sağlayabilmektedir.

Gelir dağılımı eşitsizliği konusu sadece az gelişmiş ülkelerin değil, gelişmekte olan ülkelerin de sorunu haline gelmektedir. Buna ilaveten gelir dağılımı eşitsizliğinin yoksullaşmayı da arttırması, 
mevcut serbest piyasa düzeni ve müdahalesiz devlet anlayışı ile çözülebilecek bir durum olmadığını göstermektedir. Gelir dağılımının yoksulluğa nispeten daha inatçı ve kalıcı bir yapıya sahip olduğu da düşünülürse, yoksulluk ile mücadelede gelir dağılımı meselesinin göz ardı edilmemesi gerektiği ve birlikte mücadele edilmesi gerektiği ortaya çıkmaktadır.

Yoksullukla mücadelede iktisadi büyüme bir çözüm yolu olarak görülse de yeterli değildir. Eğitim, sağlık, ulaşım başta olmak üzere birçok makroekonomik göstergede istikrarın sağlanması adına iktisadi büyüme çeşitli politikalar ile desteklenmelidir. Özellikle gelir düzeyini arttırmanın yanında işçilerin çalışma saatleri, özlük hakları ve güvenli iş ortamları gibi konularda iyileştirmeler yapılarak toplumsal refahın artmasına ve bireylerin insani yaşam standartlarına ulaşması sağlanmalıdır.

\section{KAYNAKÇA}

Abay, Ç. ve Sezgin, S. (2018). "Türkiye ve Bazı AB Ülkelerinde Yoksulluk ve Gelir Dağılımı”, Journal of Life Economics, 5(4): 97-110, Ekim.

Acar, İ. (2015). “Türkiye' de Gelir Dağılımı”, HAK-İş Uluslararası Emek ve Toplum Dergisi, 4(8).

Akın, F. (2015). “Gelir Dağılımı ve Gelir Dağılımına Müdahale Gereği”, İş ve Hayat Dergisi 1(1), 925

Alkin, E. (1995). “Türkiye'de Gelir Dağılımı”, Yeni Türkiye,141-144.

Aren, S. (1989). "Paylaşım, Demokrasi ve Sosyalist Parti", Bir Dönemden Yazılar 1980-1988, İstanbul: Gerçek Yayınevi.

Beken, H. G. (2006). "Yoksulluk Olgusuna Kavramsal Bir Bakış", Yüksek Lisans Tezi, Marmara Üniversitesi, İstanbul.

Burkhauser, R. V., Crews, A. D. and Daly, M. C. (1997). "Recounting Winners and Losers in the 1980s: A Critique of İncome Distribution Measure Ment Methodology", Economic Letters, 54, pp. 35-40.

Çalışkan, Ş. (2010). “Türkiye'de Gelir Eşitsizliği ve Yoksulluk, Sosyal Siyaset Konferansları”, 2 (59), 89-132.

Danışoğlu, A. Ç. (2004). “Küreselleşmenin Gelir Eşitsizliği ve Yoksulluk Üzerine Etkileri”, İstanbul Ticaret Üniversitesi Sosyal Bilimler Dergisi, 160.

Elveren, A. Y. (2013). "Gelir Dağılımı Çalışmaları İçin Bir Alternatif: Texas Üniversitesi Eşitsizlik Projesi Veri Setleri”, Anadolu Üniversitesi Sosyal Bilimler Dergisi, 13(2), 35-42.

Erdem, T. (2009). "Feodaliteden Küreselleşmeye”, Lotus Yayınları, Ankara

Güneş, Z. (2009). “Türkiye'de Yoksulluk Araştırmaları, 1990 Sonrası Çalışmaların Bibliyografik Analizi”, Yayınlanmamış Yüksek Lisans Tezi, İstanbul.

İzgi, B. B. ve Alyu, E. (2018). "Yoksulluk ve Gelir Dağılımı Eşitsizliği: OECD ve AB Ülkeleri Panel Veri Analizi", Gaziantep University Journal of Social Sciences, 17 (3), 9887-996.

Kabaş, T. (2010). “Gelişmekte Olan Ülkelerde Yoksulluğun Nedenleri Ve Yoksullukla Mücadele Yolları, Adana: Nobel Kitabevi.

Kalaycı, S. ve Öztürk, A. (2017). "Türkiye'de Eğitim, İşsizlik ve Enflasyona Dayalı Gelir Dağılımı Adaletsizliği”, Turkish Studies International Periodical for the Languages, Literatureand History of Turkishor Turkic Volume 12/31, p. 151-168. 
Kalayc1, S., Öztürk, A. ve Gündüz, M. A. (2017). "Kuzey Avrupa ve Latin Amerika Ülkeleri Arasında Gelir Dağılımı Adaletsizliği Açısından Ekonometrik Bir Analiz", Electronic Turkish Studies, 12(29).

Karluk, S. R. (2005). "Cumhuriyetin İlanından Günümüze Türkiye Ekonomisinde Yapısal Dönüşüm”, 10. Bask1, İstanbul: Beta.

Kartal, N., Demirhan, Y., (2014). “Türkiye'de Kentsel Yoksulluğun Kırsal Nedenleri ve Çözüm Önerileri Üzerine", C.Ü. İktisadi ve İdari Bilimler Dergisi,15-2, 135-154.

Katar, B. (2017). "Neoliberal Politikaların Gelir Dağılımı ve Yoksulluk Üzerine Etkileri”, Çukurova Üniversitesi Sosyal Bilimler Enstitüsü, Doktora Tezi.

Kayalıdere, G. ve Şahin, H. (2014). "Sosyal Devlet Anlayışı Çerçevesinde Türkiye'de Sosyal Koruma Harcamalarının Gelişimi ve Yoksulluk", Siyaset, Ekonomi ve Yönetim Araştırmaları Dergisi, $2(2)$.

Kaynak, M. (2007). “Kalkınma İktisadı” Ankara: Gazi Kitabevi.

Kuştepeli, Y. R. ve Halaç, U. (2004). “Türkiye'de Genel Gelir Dağılımının Analizi ve İyileştirilmesi.

Marasalı, Ö. S. (2018). “Türkiye’de Gelir Dağılımı”, İnönü Üniversitesi Sosyal Bilimler Enstitüsü, Yüksek lisans Tezi.

Sapancalı, F. (2005). "Sosyal Dışlanma”, 1.Bask1, Dokuz Eylül Yayınları, İzmir.

Selim, R., Günçavdı, Ö. ve Bayar, A. A. (2014). "Türkiye'de Bireysel Gelir Dağılımı Eşitsizlikleri: Fonksiyonel Gelir Kaynakları ve Bölgesel Eşitsizlikler”, TÜSİAD, 2014-06, 15-201.

Şahin, H. (2007). “Türkiye Ekonomisi”, 9. Baskı, Bursa: Ezgi Yayınları.

Şenses, F. (2006). “Küreselleşmenin Öteki Yüzü Yoksulluk”, İletişim Yayınları, 4.baskı, İstanbul.

The United Nations Development Programme (UNDP). (1997). "Human Development Report", Oxford University Press, New York.

Todaro, M. P. (2000). “Economic Development”, Seventh Edition, Addison Wesley, Massachusetts.

Türkiye İstatistik Kurumu (TÜİK). Gelir Dağılımı ve Yaşam Koşulları İstatistikleri, http://www.tuik.gov.tr/PreTablo.do?alt_id=1011, (Erişim Tarihi: 13/05/2019)

Türkiye İstatistik Kurumu (TÜIK). Yoksulluk İstatistikleri, http://www.tuik.gov.tr/PreTablo.do?alt_id=1013, (Erişim Tarihi: 13/05/2019)

Üzümcü, A., Korkat, M., (2014). "Türkiye'de Gelir Dağılımı Adaletsizliği ve Yoksullukla Mücadelede Sosyal Yardımların Gelişimi (2003-2012)", Kafkas Üniversitesi İktisadi ve İdari Bilimler Fakültesi Dergisi Cilt 5, Sayı 8, 135-166.

World Bank (WB). Yoksulluk Göstergeleri, https://data.worldbank.org/indicator/SI.POV.GINI?end=2015\&locations=1W\&start=1981\&vi ew=chart, (Erişim Tarihi: 13/05/2019)

World Bank and the State Institute of Statistics, Turkey (WB). (2005). "Turkey Joint Poverty Assesment Report, Report No. 29619-TU", August 8, http://documents.worldbank.org/curated/en/910241468312641389/Main-report, (Erişim Tarihi: $13 / 05 / 2019)$

Yazgan, T. (1975). "Gelir Dağılımı Açısından Sosyal Güvenlik”, İstanbul: Fatih Gençlik Vakfı Matbaası. 